\title{
EVALUATION OF THE POTENTIAL OF SASOBIT POLYMER AS AN ADDITIVE IN BITUMEN AND ASPHALTIC CONCRETE
}

\author{
Mohammed, H. ${ }^{1}$ and Adefesobi, S. A. ${ }^{2}$ \\ ${ }^{* 1}$ Department of Civil Engineering, Obafemi Awolowo University, Ile-Ife, Nigeria and ${ }^{2}$ Department of Civil \\ Engineering, University of Ibadan, Ibadan \\ *Email of Corresponding Author: hmesteem@yahoo.com, hmohammed@oauife.edu.ng \\ (Received: 2nd December, 2019; Accepted: 3rd April, 2020)
}

\section{ABSTRACT}

\begin{abstract}
This paper evaluated the effects of sasobit polymer (Sasobit $\left.{ }^{\circledR}\right)$ on the characteristics of asphaltic concrete with a view to investigating its suitability as an additive in asphaltic concrete. Sasobit ${ }^{\circledR}$, bitumen and aggregates were procured from a Construction Company site office, along Shagamu-Ibadan expressway. Sasobit ${ }^{\circledR}$ modified bitumen was prepared by adding Sasobit ${ }^{\circledR}$ to bitumen with increasing weight of Sasobit $\AA$ at 1.0, 1.5, 2.0, 2.5 and $3 \%$ by the weight of the bitumen. Penetration and softening point tests were carried out on the samples and the mix-ratio for the bitumen - polymer mixture was determined. Asphaltic concrete samples with and without Sasobit ${ }^{\circledR}$ were prepared. The samples were subjected to Marshall Stability test. The stability, flow, specific density, voids filled with bitumen (VFB), air voids (VA) and voids in the mineral aggregate (VMA) were determined. The values of stability, flow, specific density, voids filled with bitumen, air voids and voids filled in the mineral aggregates for sample without Sasobit ${ }^{\circledR}$ were $13.63 \mathrm{kN} 2.91 \mathrm{~mm}, 2.51,64.64 \%, 4.29 \%$ and $18.19 \%$,

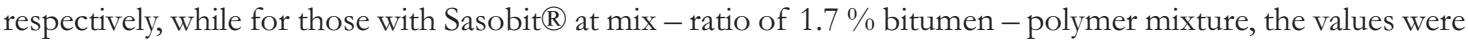
$14.67 \mathrm{kN}, 2.41 \mathrm{~mm}, 2.55,73.30 \%, 3.96 \%$ and $16.39 \%$ respectively. The result showed that, Sasobit ${ }^{\circledR}$ as additive in asphaltic concrete improved its properties.
\end{abstract}

Keywords: Sasobit ${ }^{\circledR}$, Asphaltic Concrete, Stability, Flow, Voids filled with bitumen, Air voids, Voids in mineral aggregate

\section{INTRODUCTION}

Longevity of asphalt road is in high demand as part of reducing expenses for public infrastructure and maintenance costs. Conventional asphalt concrete pavement has several draw backs. It is susceptible to rutting caused by traffic load and damage caused by petroleum oils (Hirato et al., 2014). Mat et al. (2014) opined that, flexible pavement deterioration can be minimized and increase in its service life ensured, if the bituminous layers are improved with regards to performance properties, such as resistance to permanent deformation, fatigue, wear, stripping, aging amongst others. The properties of the binder in asphaltic concrete pavement govern its performance as studies have shown that pavement distresses are related to the rheological properties of the binder (Taher and Aman, 2017). Modifiers can improve the properties of asphaltic concrete mixtures; such as stiffness, which at normal service temperatures will increase rut resistance and at low temperatures improve its resistance to thermal cracking (Roberts etal., 1996).
Application of modifiers to asphalt mix results in its improved properties compared to conventional mixture (Gawel et al., 2011).

In evaluating a modifier for bitumen, consideration should be given to its ability to flow, as this makes it workable for contractors to produce and lay bituminous materials and, its elasticity which predominates at lower pavement temperatures and gives the bituminous material its structural integrity (O'Flaherty, 2002).

Damage to roads in Nigeria is caused by environmental factors, overloading and construction malpractices. As a tropical country, Nigeria has a problem with increases in the road surface temperature. Therefore a surface layer able to resist temperature changes is desirable (Adebayo and Mohammed, 2016).

This paper therefore evaluated the effects of Sasobit ${ }^{\circledR}$ on the characteristics of asphaltic concrete with a view to investigating its potential as a additive in asphaltic concrete. 


\section{MATERIALS AND METHODS}

Sasobit ${ }^{\circledR}$, bitumen and aggregates were procured from a construction company site office at Shagamu-Ibadan expressway. Grading, specific gravity and water absorption tests were carried out on the aggregates, while specific gravity, penetration and softening point tests were done for the bitumen using standard procedures. Sasobit ${ }^{\circledR}$ modified bitumen was prepared by adding Sasobit ${ }^{\circledR}$ to bitumen with increasing weight of Sasobit ${ }^{\circledR}$ at 1.0, $1.52 .0,2.5$ and $3 \%$ by the weight of the bitumen. Penetration and softening point tests were carried out on the samples and the mix-ratio for the bitumen polymer mixture was determined (SASOL Wax Company, 2004). The optimum value of the binder used for the study was determined from the mix design (Garber and Hoel, 2015). Asphaltic concrete samples with and without Sasobit ${ }^{\circledR}$ were prepared. The samples were subjected to Marshall Stability test using standard procedure. The stability, flow, specific density, voids filled with bitumen (VFB), air voids (VA) and voids in the mineral aggregate (VMA) were determined.

\section{RESULTS AND DISCUSSIONS}

The aggregate grading curve as shown on Figure 1 , indicates that the grading falls within the grading envelope of the General Specifications (Roads and Bridges), while 2.79 and $0.44 \%$ were the determined values for specific gravity and water absorption factor respectively. This means that the materials were suitable for the asphaltic concrete (Federal Ministry of Works and Housing, 1997).

The values of the specific gravity, penetration and softening tests for the bitumen were 1.02, $65 \mathrm{~mm}$ and $48.3^{\circ} \mathrm{C}$ respectively. These values showed that the bitumen conforms to all the requirements for asphaltic concrete production (Clause 6371, Table VI-15, FMWH, 1997).

The result of the penetration and softening point tests for the Sasobit ${ }^{\circledR}$-bitumen mixture is as shown in Table 1, while Figure 2 shows the graph of Sasobit $\AA$, penetration and softening tests.

The penetration value decreases as the content of

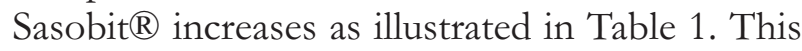
indicates a more viscous and harder mix, which would be useful to obtain stiffer asphaltic concrete (Hainin et al., 2014). This is also an indication of an enhanced resistance against permanent deformation of the asphaltic concrete using Sasobit ${ }^{\circledR}$ modified bitumen during the service life of pavement. The results of soften tests show that as the Sasobit ${ }^{\circledR}$ content increases, the softening point of mix also increases. This implies that the modified bitumen will be less susceptible to temperature changes as the content of Sasobit ${ }^{\circledR}$ increases (Mat et al., 2014). A mix ratio value of $1.7 \%$ was therefore used for the asphaltic concrete mix. This value is within the range of 0.8 $-4 \%$, usually adopted (Hurley and Prowell, 2011).

Table 1: Bitumen Test Results

\begin{tabular}{ccc}
\hline $\begin{array}{l}\text { Percentage of } \\
\text { Sasobit }\end{array}$ & Penetration Test $(\mathrm{mm})$ & Softening Point Test $\left({ }^{\circ} \mathrm{C}\right)$ \\
\hline 0 & 65 & 48.3 \\
1.5 & 51 & 59.3 \\
2.0 & 48 & 65 \\
2.5 & 40 & 69.3 \\
3.0 & 33 & 73.3 \\
\hline
\end{tabular}

The Marshall test property curves are as shown on Figure 3, while the mix design properties are as shown on Table 2. The result shows that the asphalt mix met the requirements of the General
Specifications (Roads and Bridges) (Federal Ministry of Works and Housing, 1997). Table 3 shows the Marshall test properties of the mixes without and with Sasobit $\AA$. 


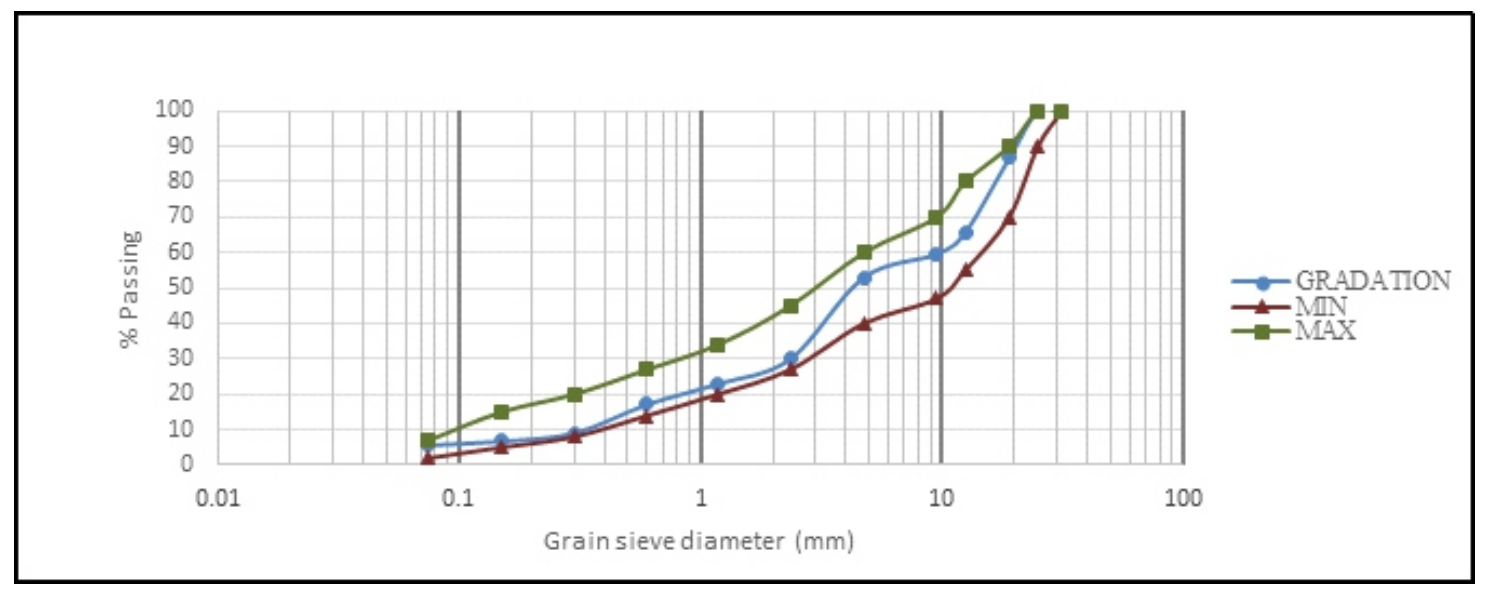

Figure 1: Mix Design Aggregate Grading Envelope

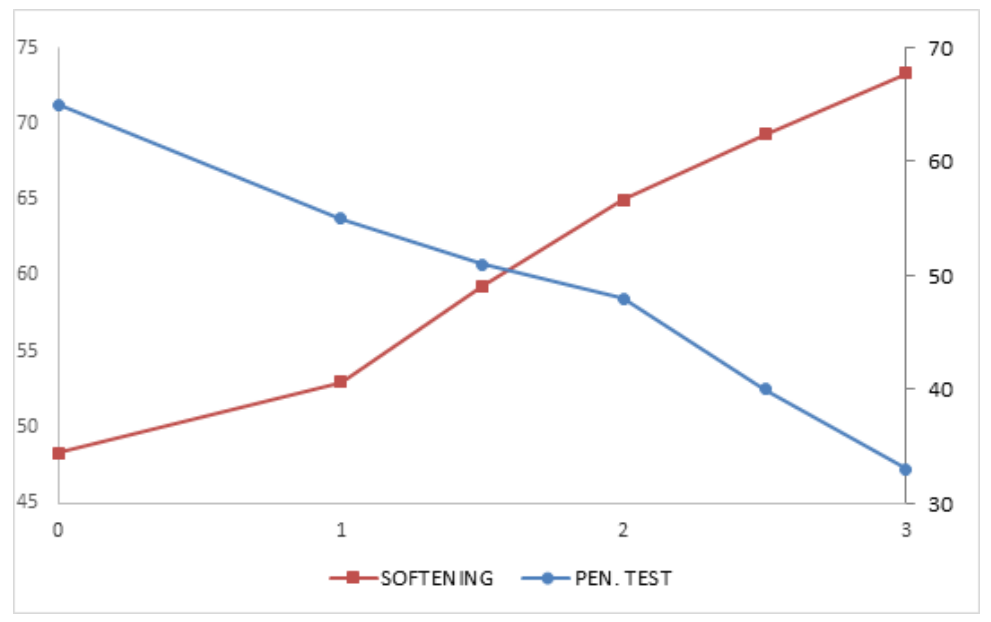

Figure 2: Sasobit ${ }^{\circledR}$ - Bitumen Mixes

Table 2: Marshall Mix Design Properties

\begin{tabular}{lccc}
\hline S/N & Properties & Optimum Values & $\begin{array}{c}\text { FMW\&H } \\
\text { Specification }\end{array}$ \\
\hline 1 & Binder Content (\%) & 5 & $4.5-6.5$ \\
2 & Stability $(\mathrm{kN})$ & 13.63 & 3.5 \\
3 & Flow (mm) & 2.91 & $2-6$ \\
4 & Voids in Total Mix (\%) & 4.5 & $3-8$ \\
5 & Voids Filled with Bitumen (\%) & 66 & $65-72$ \\
\hline
\end{tabular}

Table 3: Marshall Test Properties

\begin{tabular}{lccc}
\hline S/N & Properties & Mix without Sasobit ${ }^{\circledR}$ & Mix with Sasobit ${ }^{\circledR}$ \\
\hline 1 & Stability $(\mathrm{kN})$ & 13.63 & 14.67 \\
2 & Flow (mm) & 2.91 & 2.41 \\
3 & Specific gravity & 2.51 & 2.55 \\
4 & Voids filled with & 64.64 & 73.30 \\
& bitumen (VFB) (\%) & 4.29 & 3.96 \\
5 & Air voids (VA) (\%) & 18.19 & 16.39 \\
6 & Voids in mineral & & \\
& aggregates (VMA) (\%) & & \\
\hline
\end{tabular}




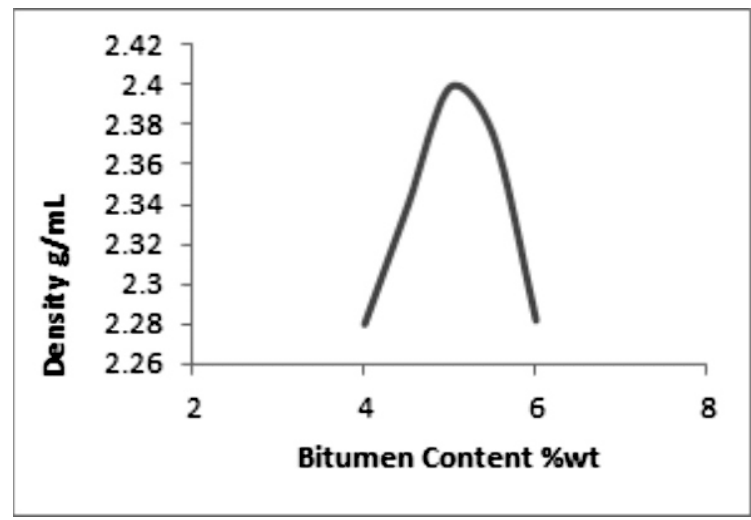

(a) Density versus Bitumen Content

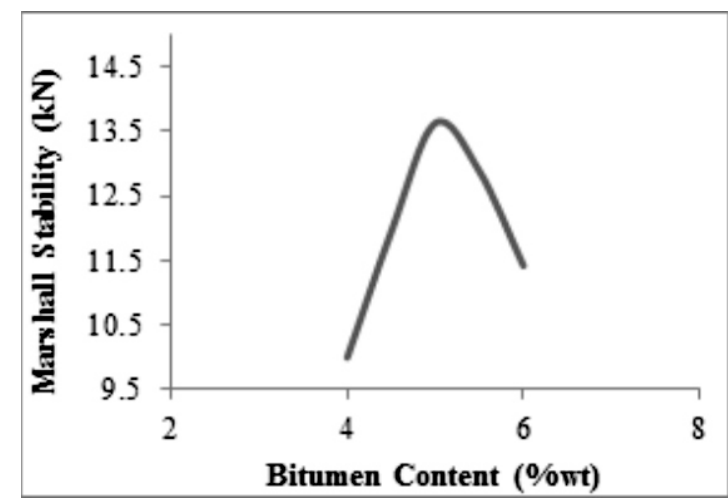

(c) Marshall stability versus Bitumen content

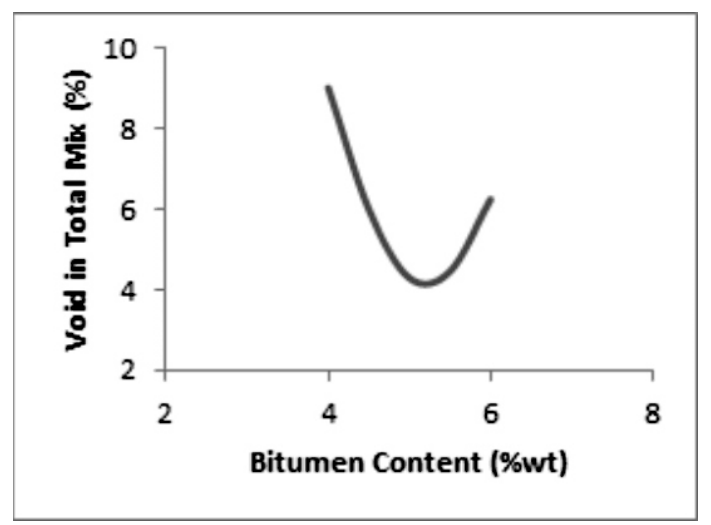

(b) Void in total mix versus Bitumen content

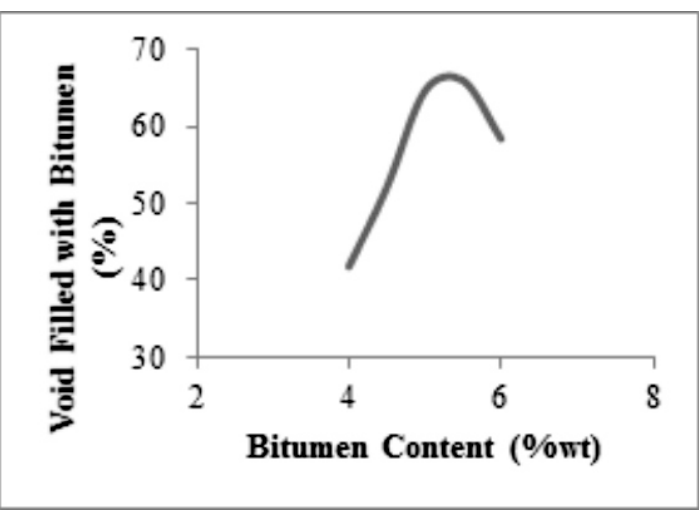

(d) Void filled with Bitumen versus Binder content

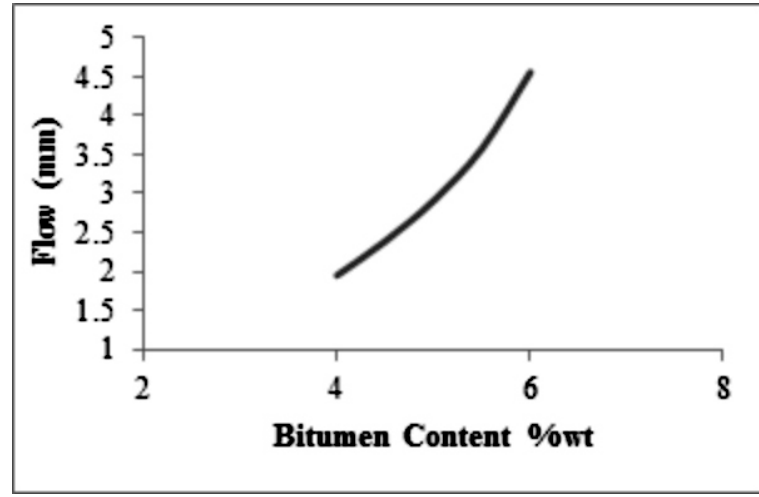

(e) Flow versus Bitumen content

Figure 3: Marshall Test Property Curves

The improved value of the stability confers higher strength on the mixes with Sasobit ${ }^{\circledR}$ and hence, better structural integrity (Kurtis, 2013). The lower flow value indicates the reduction of viscosity of the binder meaning decrease in mixing and compaction temperatures, mix workability and decrease in rutting potential as well as better elasticity of the pavement. The improved value of the specific density confers more strength on the Sasobit ${ }^{\circledR}$ mix. Better flexible mix is ensured in the Sasobit ${ }^{\circledR}$ mix as a result of the higher binder content in the mix as shown by the higher value of voids filled with bitumen (VFB). Air voids (VA) and voids in mineral aggregate (VMA) values are lower in the Sasobit $\AA$ mix; indicating mix impermeability. Impermeability is maximised at higher binder content, with dense aggregate gradations and good compaction (Kurtis, 2013). 


\section{CONCLUSION}

Based on the findings obtained, it can be deduced that the specific gravity of 2.79 and the water absorption factor of $0.44 \%$ for the aggregates as well as its grading met the specifications for asphaltic concrete production. The physical properties of the bitumen, viz; specific gravity, 1.02 , penetration, $65 \mathrm{~mm}$ and softening point, 48.3, also met the specifications. The mix ratio of Sasobit ${ }^{\circledR}$ - bitumen is within the usually adopted value. The Marshall Stability test results meet the specification for asphaltic concrete. Sasobit ${ }^{\circledR}$ in bitumen and asphaltic concrete enhanced their properties. Thus Sasobit ${ }^{\circledR}$ as additive improved the properties of asphaltic concrete.

\section{REFERENCES}

Adebayo, V. B. and Mohammed, H. (2016). Pulverized Coconut Fibre as an Additive in Asphaltic Concrete, International Journal of Materials and Technologies, 4(1): 10.

Federal Ministry of Works and Housing. (1997). General Specifications (Roads and Bridges), Volume II. Federal Ministry of Works and Housing, Nigeria.

Garber, N. J.and Hoel, N. A. (2015). Traffic and Highway Engineering. Cengage Learning, Stamford, USA.

Gawel, J., Pilat, P., Radziszewski, k. j. and Krol, J. B.(2011). Polymer Modified Bitumen (Properties and Characterisation), Woodhead Publishing Series in Civil and Structural Engineering, pp 72-97.

Hainin, M. R., Jaya, R. P., Ali Akbar, N. A., Jayanti, D. S., Yusoff, N. I. M. 2014. Influence of palm oil fuel ash as a modifier on bitumen to improve aging resistance. Journal of Engineering Research. 2(1) 34-46.

Hirato, T., Murayama, M. and Sasaki, H. (2014). Development of high stability hot mix asphalt concrete with hybrid binder, Journal of Transportation Engineering, 1(6) 424-431.

Hurley, G. C. and Prowell, B. D. (2005). Evaluation of Sasobit for Use in Warm Mix Asphalt. Auburn: National Center for Asphalt Technology, Auburn University, USA.

Kurtis, K. (2013). Asphalt and Asphalt Concrete. http:/ / people.ce.gatech.edu / kk92/asplarger.pdf. Retrieved on 28th April, 2013.

Mat, N. C., Jaya, R. P., Hassan, N. A., Nor, H. M., Aziz, M. M. A., Wan, C. N. C. (2014). Properties of Asphaltic Concrete Containing Sasobit ${ }^{\circledR}$. Jurnal Teknologi, Penerbit UTM

Press, Malaysia.

O'Flaherty, C. A. (2002). HIGHWAYS (4th ed.). New Delhi, India: ELSEVIER.

Roberts, F. L, Kandhal, P. S, Brown, E. R., Lee, D. Y. and Kennedy, T. W. (1996). Hot Mix Asphalt Materials, Mixture Design and Construction. National Asphalt Pavement Association Education Foundation, Lanham, MD.

SASOL Wax Company (2004). SASOL. SASOL Wax Company. South Africa.

Taher, M. N. M. and Aman, M. Y. (2017). Effecte of Advera Warm Mix Additive on the Rheological Properties of Unaged and Short Term Aged Asphalt Binders, Journal of Fundamental and Applied Sciences, 9(7S), 650-666. 